\title{
Geslagsinklusiewe taalgebruik
}

In 'n vorige taalrubriek (19) is die kwessie van die vervrouliking van nielewende sake in Afrikaans bespreek, veral wat betref die gebruik van die vroulike voornaamwoorde sy en haar wanneer daar verwys word na kollektiewe begrippe soos organisasies en instellings, maar ook abstrakte begrippe, soos byvoorbeeld tale.

Die motivering vir hierdie verskynsel is waarskynlik te vind in die poging om so geslagsinklusief moontlik te wees by die gebruik van die voornaamwoorde. Dit is ' $n$ beginsel wat ook in die 2020-vertaling van Die Bybel genoem word, en is relatief probleemloos wanneer daar sprake is van biologiese geslag. In die Nuwe Testament word daar op 'n hele aantal plekke daarna verwys dat, volgens die opvatting van die tyd, die woord vir "broers" ook susters insluit. ${ }^{1}$ Dit word telkens met 'n voetnoot aangedui. Om in die geval van lewende referente, soos persoon of individu, 'n geslagsinklusiewe voornaamwoord te gebruik, kies outeurs soms die meervoudsvorm in 'n taal soos Engels, wat, anders as in byvoorbeeld Frans of Italiaans, nie na geslag verwys nie. As die gebruik van die enkelvoud noodsaaklik is, word $h y / s y$, of sy of hy geskryf. Om in so 'n geval slegs $s y$ te gebruik, sluit by wyse van implikasie 'n beduidende deel van 'n bevolking uit.

Wanneer biologiese geslag in die Bybelteks egter nie 'n bepalende faktor is nie, soos in die geval van nielewende sake, noem die Voorwoord in die Bybelvertaling die feit dat Afrikaans dikwels die voornaamwoord hy (en die gepaardgaande vorme hom en sy) as grammatikaal geslaglose vorm, pleks van dit, gebruik. Dit is 'n erkende beginsel in Afrikaans, in teenstelling met Hebreeus en Grieks, waar die betrokke voornaamwoord bepaal word deur die grammatikale geslag van die naamwoord, wat manlik, vroulik of onsydig kan wees.

'n Uitsondering word egter in hierdie vertaling gemaak in die geval van poëtiese taalgebruik waar sulke nielewende sake, byvoorbeeld stede en abstrakte begrippe soos wysheid, simbolies as biologies vroulik voorgestel word. (Soms stem dit ook, byvoorbeeld in Grieks, ooreen met die grammatikale geslag, waardeur die simboliese waarde/funksie in Afrikaans verder versterk word.) 'n Voorbeeld van sulke simboliese taalgebruik kom voor in Openbaring 21:2 en 22:22:

En ek het die heilige stad, die Nuwe Jerusalem, van God af uit die hemel sien neerdaal. Sy is gereedgemaak, soos ' $n$ bruid wat versier is vir haar man.

'n Tempel het ek egter nie in haar gesien nie, want die Here God, die Almagtige, en die Lam is haar tempel.

Hierdie simboliese vervrouliking van begrippe stem ooreen met ' $n$ beginsel waarvolgens dit ook in Engels voorkom. Onderstaande opmerking ${ }^{2}$ is insiggewend:

She is occasionally used in formal and deliberately archaic oratorical references to abstract large entities, like countries, universities and other abstract corporate bodies, like "the [Christian] Church", weather/nature, etc. Many of these are traditionally associated with feminine gender, and specifically mothers ("Mother Church", "Mother Nature", etc.)

Vergelyk Handelinge 21:17.

https://english.stackexchange.com/questions/287721/pronoun-question-referring-to-inanimateobjects-as-he-or-she. [08-11-2021] (Die English Language \& Usage Stack Exchange is 'n vraag-en-antwoord-webwerf vir linguiste, etimoloë en ernstige entoesiaste vir die Engelse taal.) 
Benewens die feit dat die "normale" gebruik van sy en haar ook in Engels in sulke gevalle as argaïes en oratories beskou kan word, is dit vanuit sosiolinguistiese of pragmatiese perspektief 'n voorbeeld van gemarkeerdheid - dit wil sê om spesifieke aandag te vestig op 'n taalvorm wat afwyk van die verstekvorm. In die geval van die voorbeelde wat uit die 2020-Bybelvertaling aangehaal is, kan 'n simboliese konnotasie daaraan geheg word, waarvoor daar ook telkens in die voetnote 'n verklaring gebied word. Indien dit egter as verstekvorm (d.w.s. niegemarkeerde, normale vorm) aangebied word, dui dit op 'n verwarring van die grammatikale met die semantiese funksie van die voornaamwoord.

Hierdie verwarring is in sommige gevalle in Afrikaans taalhistories verklaarbaar. Die verwysing in byvoorbeeld kerktaal na 'n gemeente of die kerk as geheel as haar (of sy as onderwerpsvorm) stam uit die gebruik van Nederlands (en veral die Statevertaling van die Bybel), wat nog tot in die 20ste eeu in formele tekste in kerkverband 'n sterk invloed uitgeoefen het. In moderne Afrikaans doen sulke vorme egter bra argaïes aan, en dit dui vir die deursneeleser op onkundigheid oor die sosiolinguistiese funksie van gemarkeerdheid. Om na 'n begrip soos 'n taal (“Afrikaans sal haar man/vrou moet staan") of 'n instelling soos 'n universiteit of ander organisasie as 'n pertinent (dus biologies) vroulike entiteit te verwys ("die universiteit open haar deure vir alle taalsprekers"), is om 'n nuwe en ongegronde inhoud en interpretasie te probeer gee by wyse van die ongedefinieerde markering van andersins neutrale voornaamwoorde. In plaas van geslagsinklusiewe taalgebruik, dui dit juis op 'n gebrek aan begrip van die onderskeid tussen grammatikaal neutrale en biologies spesifieke voornaamwoorde.

\section{Gasskrywer: Prof. (em.) Ernst F. Kotzé}

E-pos: ernst.somerstrand@gmail.com

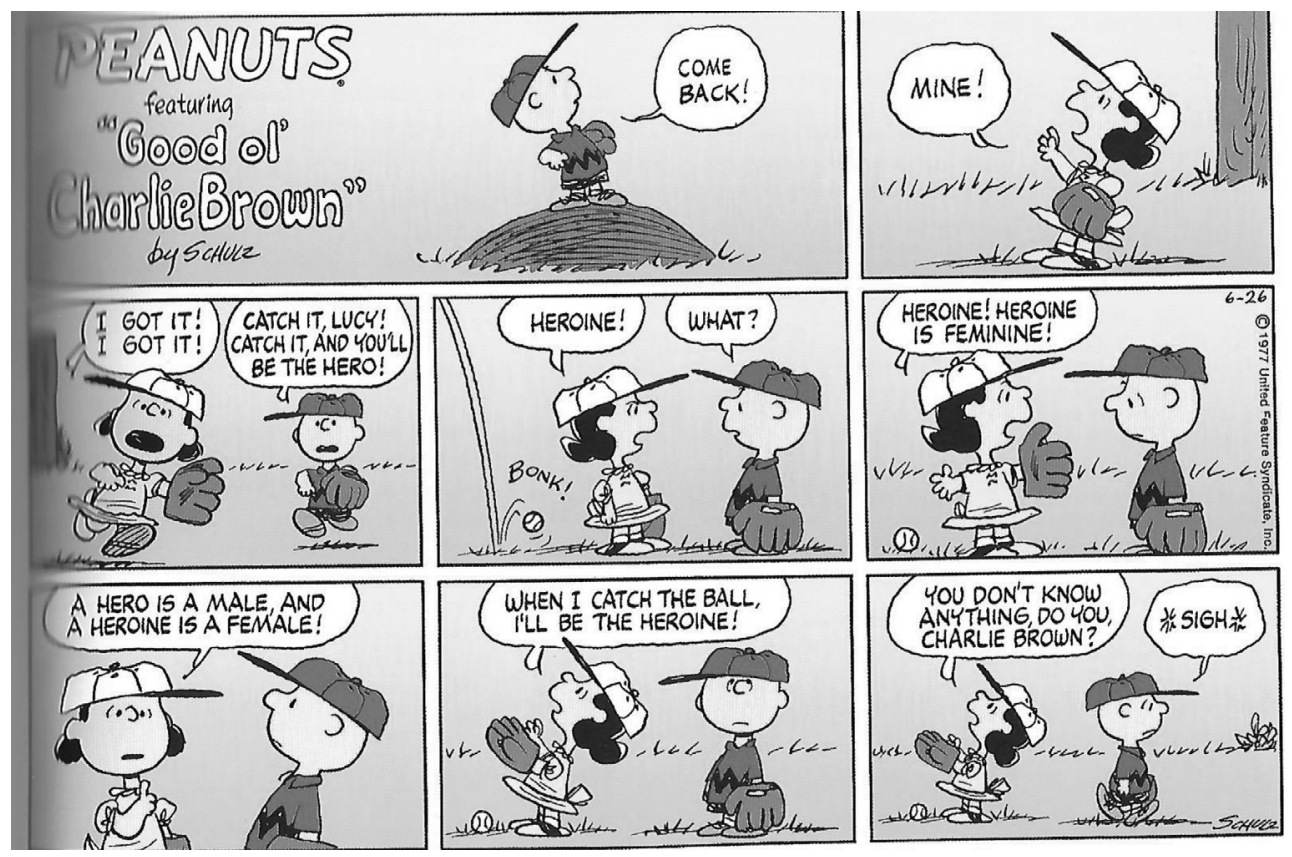

